\title{
Living with HIV: coping strategies of seropositive older adults*
}

\author{
Convivendo com o HIV: estratégias de enfrentamento de idosos soropositivos \\ Conviviendo con el VIH: estrategias de enfrentamiento de personas mayores seropositivas
}

How to cite this article:

Brandão BMGM, Angelim RCM, Marques SC, Oliveira RC, Abrão FMS. Living with HIV: coping strategies of seropositive older adults. Rev Esc Enferm USP. 2020;54:e03576. doi: https://doi.org/10.1590/S1980-220X2018027603576

\section{Brígida Maria Gonçalves de Melo Brandão'}

(D) Rebeca Coelho de Moura Angelim ${ }^{1}$

\section{Sergio Corrêa Marques ${ }^{2}$ \\ Regina Célia de Oliveira ${ }^{1}$ \\ Fátima Maria da Silva Abrão ${ }^{1}$}

${ }^{*}$ Extracted from the dissertation: "Representações sociais de idosos soropositivos acerca do HIV/

Aids: desvelando o enfrentamento da doença”,

Programa Associado de Pós-Graduação em

Enfermagem, Universidade de Pernambuco/

Universidade Estadual da Paraíba, 2017.

${ }^{1}$ Universidade de Pernambuco, Programa

Associado de Pós-Graduação em

Enfermagem, Recife, PE, Brazil.

${ }^{2}$ Universidade do Estado do Rio de

Janeiro, Programa de Pós-Graduação em

Enfermagem, Rio de Janeiro, RJ, Brazil.

\section{Corresponding author:}

Brígida Maria Gonçalves de Melo Brandão Universidade de Pernambuco, Programa

Associado de Pós-Graduação em Enfermagem

Rua Arnóbio Marques, 310, Santo Amaro.

CEP 50100-130 - Recife, PE, Brazil

bri.melo@hotmail.com

\section{ABSTRACT}

Objective: To identify HIV coping strategies among HIV-positive older adults. Method: An exploratory-descriptive study with a qualitative approach conducted with HIVpositive older adults in two HIV Specialized Care Services and using the Theory of Social Representations as a theoretical framework. A semi-structured interview technique was used, which was analyzed by the lexical analysis method using the IRAMUTEQ software program. Results: Forty-eight (48) older adults participated in the study. The HIV coping strategies adopted by HIV-positive older adults are to cling to religiosity and spirituality, to adhere to treatment, to have institutional support from health professionals and support from social networks, especially family and friends, and to choose to maintain confidentiality of the diagnosis. Conclusion: HIV coping strategies, among other things, are configured for seropositive older adults as sources of empowerment, hope, possibility of life and acceptance.

\section{DESCRIPTORS}

Aged; HIV; Adaptation, Psychological; Social Support; Geriatric Nursing. 


\section{INTRODUCTION}

There has been a change in the course of the HIV/AIDS epidemic disease with its evolution in recent years, since the epidemiological profile has shown a gradual increase in cases in the age group of 50 years or older in both genders ${ }^{(1-2)}$, resulting in an increase in older people living with HIV.

Such a reality may be related to social and individual aspects. In other words, it can be the result of both unfavorable socio-demographic and economic conditions, as well as the lack of information ${ }^{(1)}$, "creating an uncomfortable situation where older adults exercise their sexuality with complete freedom in the sense that they do not protect themselves and feel immune, and on the other hand the society and health professionals who believe they are asexual"(3).

Thus, health professionals sometimes do not investigate HIV among older people, and due to age-related immune system weakness coupled with the lack of suspicion regarding a diagnosis, they may therefore present AIDS symptoms which are confused with a common manifestation of aging or with another chronic disease ${ }^{(4)}$. Thus, the ideal situation is that HIV investigation in older adults becomes part of the routine of professionals, since the earlier the diagnosis, the better the patient's prognosis ${ }^{(5)}$.

In this context, the discovery of HIV infection among older adults requires a new look at life as a way to adapt and positively manage the challenges arising from the diagnosis, thus aiming toward developing coping strategies in order to face living with $\mathrm{HIV}^{(6)}$. These strategies serve as mechanisms to alleviate suffering, conflict, and weakness, thus empowering people, giving hope, and increasing their resistance to stress.

In view of the above, the aim of this study was to identify strategies for coping with HIV among HIV-positive older adults.

\section{METHOD}

\section{Study Design}

An exploratory-descriptive study implementing a qualitative approach.

\section{SCENARIO}

The study was developed in two HIV Specialized Care Services $(S A E)$ located in public hospitals in the metropolitan region of Recife, Pernambuco, Brazil. It is noteworthy that Recife has eight $S A E$, and the choice for these two was because they serve a larger number of people living with the virus, as according to data provided by the institutions themselves; one had 6,806 registered patients, and the other, 2,630 patients.

Both institutions stated that they did not have control over the number of patients treated according to age group in their system; a fact which made it impossible to reach an exact number of the older adult population in the referenced SAE.

The Theory of Social Representations (TSR) was used in its procedural approach as a theoretical framework. "Social representations demonstrate the way in which individuals understand everyday events, indicating common sense theories based on their knowledge of their position regarding conflicting events" ${ }^{(7)}$.

\section{Population}

Forty-eight (48) older adults who met the following inclusion criteria were selected by convenience to participate in this study: age 50 years or older, diagnosed with HIV for at least 6 months, and outpatient follow-up in one of the SAE included in the study. Any people without the necessary cognitive conditions to participate were excluded. The choice of the number of participants to compose the sample was guided by a consensus which exists among theorists studying TSR, which considers 30 as the minimum number to define a representation ${ }^{(8)}$. Thus, the data saturation criterion was considered from this minimum number.

Participants were collected at the outpatient clinic during the day shift by oral invitation to participate in the study by order of arrival of patients for medical consultation, followed by the signing of the Informed Consent Form (ICF) and consequent application of data collection instruments. There was no dropout during data collection.

\section{Data collection}

Data collection was carried out from April to May 2017 using a sociodemographic and clinical questionnaire extracted from a validated instrument ${ }^{(9)}$, and a semi-structured interview script prepared by the authors, containing questions which explored the representational contents about $\mathrm{HIV}$, aspects inherent to the diagnosis, and coping strategies for living with HIV.

\section{DATA ANALYSIS AND PROCESSING}

The interviews were audio recorded with the consent of the participants, with subsequent transcription and preparation of the corpus for analysis. The average duration of each interview was 24 minutes. The participants are identified with the letter "I" derived from the word Interviewee in order to preserve their identity, along with the sequence number of the interview (example: I1).

After the database was organized, it was inserted and processed in the software Interface de $R$ pour lês Analyses Multidimensionnelles de Textes et de Questionnaires (IRAMUTEQ), in which a brief description of its contents was obtained. One opted for subsequent analysis using the Descending Hierarchical Classification (DHC) method.

Each text was evaluated and divided into text segments by $\mathrm{DHC}$, which were classified according to their vocabularies, constituting lexical classes. The contents of two classes which addressed the coping strategies of HIV-positive older adults about HIV were analyzed and discussed in this study, since it was in these that the excerpted object for discussion was found.

\section{ETHICAL ASPECTS}

The study development complied with national and international standards of ethics in research involving human 
beings, in particular in relation to Resolution 466/2012 of the National Health Council and was approved by the Research Ethics Committee of the Hospital Complex at Oswaldo Cruz University Hospital/Cardiac Emergency Department of Pernambuco (CEP HUOC/PROCAPE), under opinion number 2.009.411/17. All participants who agreed to participate in the study signed the Informed Consent Form (ICF).

\section{RESULTS}

The 48 older adult participants in the study were between 51 and 72 years old, most were male (58.3\%), aged 61 to 65 years $(31.2 \%)$, heterosexual $(75.0 \%)$, single $(39.6 \%)$, with incomplete elementary school (41.7\%) and Catholic (47.9\%). Most of the participants (29.2\%) were in the period between 5 and 10 years regarding the time since diagnosis.

The analysis of textual data enabled identifying the following categories: Religiosity and spirituality; Adherence to treatment; Institutional Support; Social support network; and Diagnostic confidentiality.

\section{Religiosity AND SPIRITUALITY}

The first category presents religion and faith in God as a strategy for coping with living with HIV.

I would say that I ask God very much for the strength to keep fighting for my exams, my consultations, my treatment (I9).

Religion helps me cope a lot. God is who sustains me to face this, and he has been very faithful in my life (I10).

The church helps me to face it, it gives me a little more hope (I11).

Religion helps me to cope (I17).

The Spiritism religion also helps me to cope (I30).

I think God helps me to confront it and especially my family (I32).

There are also reports of hope placed in God's action towards HIV, in which the confidence of the HIV-positive older adults can be perceived in either a miracle or in scientific success in coping the disease.

God created the laboratory and gave intelligence to man. My faith in God helps me a lot to cope (I19).

God enables humans to discover these medications and through them we succeed (I35).

But nothing is impossible to God. God has already healed me of cancer, so He can cure me of HIV (I42).

Religiosity and spirituality strengthen older people with HIV in facing their sickness, helping them to have their hopes renewed and contributing to a subjective well-being.

\section{AdHeSION TO TREATMENT}

The second category reveals adherence to treatment as another strategy for coping with HIV and is of great value when considering treatment, especially antiretroviral drugs as a way of survival and for improving the quality of life.
This treatment is a great thing and is very important for me to live a little longer (I3).

The treatment is very important, it's my life. If it wasn't for it, I don't know if I would be alive (I7).

For me, the treatment is there for me to get well. I mean, well, I won't get better, but I keep taking the medicine, which is a way to help me cope until it's time to die. This treatment means that I am alive (I8).

My real thought is that I have to take this medicine because it is God to me (...) I don't think I will die without God allowing it, and the antiretroviral doesn't allow it, and I lead a normal life (I10).

This treatment is great and this antiretroviral is very important because if I run out of medication the tendency is to get worse (I17).

Treatment means I can have a better life expectancy, because by taking the antiretroviral drug properly, in the future I may even die from something that has nothing to do with HIV (I26).

I cope by taking the antiretroviral drug (I29).

Adherence to treatment is a form of self-care, contributing to adapting to the new life after diagnosis.

\section{INSTITUTIONAL SUPPORT}

The third category complements the previous category, since information and attention of health professionals to older adults in the context of treatment adherence were listed as important social support mechanisms for coping with $\mathrm{HIV}$, as a relationship of trust between patient, doctor and other team members is one of the factors which positively influences adherence.

The treatment I receive from service professionals, my doctor and others is very important to me. Thank God for this treatment (I7).

The psychologist was talking to me and that's when I reacted, I got better and started thinking the way I think now. The moment I started talking to the psychologist everything got better in my head, I confronted it, standing firm and I didn't listen to what they thought of me and kept talking (I10).

Treatment is a way to fight HIV, I know I have to continue with it until the end of my life. The treatment by the professionals $I$ receive here I also find excellent, from the attendants to the doctors (I13).

Here at SAE there is care and concern that health professionals have with us, and out there, there isn't. They [health professionals] helped me a lot and gave me a lot of strength to face it. This treatment is my life because a person with HIV gets very weak and then recovers. It's like a plant root dying in the sun, then the person puts it in their house and waters it and it returns. So the treatment is that. I'm very grateful for the medicine and the people who work here (I20).

The staff is very good. In addition to fighting the disease, the professionals gave me very important mental and spiritual strength (I22).

It can be seen that the dialogue and welcoming fostered by the health team contribute to the older adults with HIV 
feeling welcome and valued, corroborating their physical and mental well-being, the process of acceptance of their health condition and adherence to the antiretroviral therapy.

\section{SOCIAL SUPPORT NETWORK}

The fourth category covers social support networks with an emphasis on family and friends as key elements in this coping process. As these are people with whom older people often live with and trust, they soon know about their diagnosis when they feel safe to tell them. Thus, the participants mentioned that family support greatly contributes to living with the virus. I faced facing it, including I had the support of my family, because all my family knows (I4).

I faced it with the help of my brothers (I8).

My family gave me a lot of support. Thank God this happened, because contempt drives man to despair (I19).

The support of my sisters helps me a lot (I26).

I face it normally. I believe my son helps me, and it strengthens me a lot (I39).

Disclosure of the diagnosis is a situation which causes distress and uncertainty in the minds of people living with $\mathrm{HIV}$, however it is known that older adults will feel more empowered to deal with the virus when receiving support and assistance from friends and family. In this sense, it can be seen that the older adults feel supported after disclosing their diagnosis when there is a supportive relationship without discrimination.

My family supported me. Thank God nothing has changed (I6).

My current wife and sister are the only ones who know. I told them from the beginning, and their relationship with me hasn't changed. They gave me a lot of support (I13).

My whole family knows, just the family. They did not isolate themselves from me, they have always treated me well and gave support (I17).

Much of my family knows and some friends. Our relationship remained the same, and they support me a lot (I34).

Today my family is more careful with me than they were before I had HIV. They support me a lot (I42).

Thus, it is clear that family members and friends can be considered two major drivers for the well-being and coping of HIV-positive older adults living with HIV. After all, the support of loved ones can help them to accept themselves and thus create mechanisms to move forward.

\section{Diagnosis CONFIDENTIALITY}

The fifth category addresses the diagnosis confidentiality as a way to address HIV seropositivity because of fear of the reaction from some family members or close relatives, choosing not to tell anyone about their condition or to disclose to only one or a few reliable people.

God forbid to tell someone I have HIV. They will want to put me aside again, they will want to despise me. I already told my sister to tell the people of the street and all the rest of my family only when I die and God has taken me (I3).

I try not to tell anyone and not be talking nonsense. There is a lot of prejudice. If they knew they would discriminate me, they would even stone me if it was possible (I6).

My son doesn't know so far. He also doesn't know that his father died of it, I didn't tell him and I don't want him to know, especially a neighbor, God forbid. If one person knows, the whole city knows. I never wanted other people to know because of prejudice, because I know that prejudice would mainly come from neighbors, because such a disease, whether you like it or not, there is always someone who has prejudice (I26).

I was embarrassed and didn't have the courage to tell the children, so much so that they don't know until today, only my wife. Besides my wife, only health professionals know (I31).

Only my daughters know in my family, because I know that if the rest of the family finds out that I have it, they will reject me (I36).

So no friend knows, no neighbor, and even worse my family, because in my family there is only snakes. Not even my daughter knows. She's a psychologist, but she's very explosive and I don't trust her (I46).

It is noted that the fear of prejudice and consequent discrimination and rejection is the main factor which leads to the option of maintaining diagnosis confidentiality from the family and society, a representation rooted in the imagination of people in general.

\section{DISCUSSION}

As shown in the results, religiosity and spirituality, adherence to treatment, institutional support, family support, and diagnostic confidentiality were defined as coping strategies for HIV.

Regarding religiosity and spirituality, it should be noted that their concepts overlap in the context of common sense and are used as synonyms; however, each has its particularities. Religiosity is an organized system of practices, beliefs or rituals in which people engage and approach the transcendental or sacred, serving as a way to express spirituality ${ }^{(10)}$. On the other hand, spirituality involves individual beliefs and represents a way for a person to connect with their faith and maintain a commitment to the divine, which may or may not culminate in religious rituals, influencing or being influenced by social, cultural, and psychological factors, among others. This means it is characterized by a personal relationship with the transcendent, of an extraphysical character, referring to something broader, which may also include religion ${ }^{(1,10-11)}$.

A study with older adults showed that spirituality and personal beliefs helped in coping with chronic disease, giving them a feeling of relief and serenity ${ }^{(12)}$. Other studies with people living with HIV reinforce this data by conceiving prayer, personal faith, and faith in some God as indispensable sources of comfort and strength when facing adversities and health issues ${ }^{(11,13-15)}$. 
Still from this perspective, research has shown that people living with HIV who had faith in God or followed a religion were able to more easily adhere to treatment and to follow it correctly compared to those who did not belong to any religious group or had faith in something sacred ${ }^{(16)}$.

Thus, it is noted that spirituality and/or religiosity is presented as a strategy for coping with HIV. It is even considered that religiosity and/or spirituality can be a strategy of self-care not on physical issues, but mental, since believing in the transcendental helps to ease the pain and face the adversities of being HIV positive.

In this context, it was possible to infer that the hope for curing HIV among the older adults is also based on faith, but in different ways, being linked to a direct relationship with the transcendental, and on the other hand mediated by God, in which man will make scientific discoveries and find the cure through the wisdom given by the divine.

In this case, it is considered that there is an association between ideas and conceptions which engender the consensual and reified universe, and in the latter, science and faith complement each other to promote the well-being and quality of life of people living with HIV.

Moreover, by identifying the social representations of individuals and the way in which they are constructed, it is possible to understand their reality and the factors which may interfere with their daily life $\mathrm{e}^{(17)}$. From this perspective, in this study it was observed that the social representations of older adults regarding HIV are composed of a set of images, concepts and positive feelings related to antiretroviral therapy (ART), which results in removing the perception of the proximity of death, creates expectations for the future and promotes closeness with family members to help coping with living with the virus.

It is noteworthy that treatment success cannot be restricted to medication alone, as adherence also involves other factors such as dietary and behavioral changes, meaning that it corresponds to the adequacy to new habits, regular appointments, periodic examinations and care with prevention, food and hygiene ${ }^{(18-19)}$. In a study with people living with HIV aged 18 years and over, including older adults, it was found that the group gave greater importance to healthy lifestyle habits including proper diet, exercise, leisure activities, more attention to sleep and rest, among other care actions for health promotion, in addition to the therapeutic program. Medications represent healthcare needed to continue living normally and to improve quality of life $\mathrm{e}^{(20)}$.

In the social thinking of the group studied in this research, treatment is considered important for coping with the disease, as it provides health, reduces morbidity and increases life expectancy. Thus, it is valid to recognize that treatment drives the desire to live and overcome the obstacles imposed; however, it is still a challenge, especially for older adults ${ }^{(21)}$.

Thus, the work of health professionals to promote a multidisciplinary approach is emphasized in this context, and they should foster a dialogue which enables patients to be prepared for starting therapy and the possible side effects which may occur, providing calmness and safety ${ }^{(22)}$. Providing sufficient health services and a welcoming attitude of professionals are key elements in the motivation to maintain treatment continuity, especially at the beginning when the psychological impact is greater and people living with HIV need to feel cared for by someone ${ }^{(23)}$.

In a study aimed at assessing the quality of life of older people, the authors found that the best scores were related to the care and respect from the health team with this clientele during care, which favored trust and bond with the older adults, in addition to contributing to adherence to $\mathrm{ART}^{(24)}$.

The health services which attend this type of clientele are care enhancers, with a reflection on the quality of life of this group, providing more humanized care with care actions that go beyond drug treatment, consultations and examinations, including psychological support, which greatly helps people in coping with living with $\mathrm{HIV}^{(20)}$.

It is noteworthy that a committed and interested multiprofessional team is reflected in the motivation of self-care among people living with HIV, as evidenced in this study by recognizing the appreciation they receive from health professionals as a foundation in coping, not only due to their skills, but also for the ethics and commitment to their care process. In addition, health education or guidance provided by health professionals is of great importance in contributing to lifestyle change in pursuit of a healthier life.

In addition to institutional support, it is worth highlighting family and friends as the main social support networks in this process. It is common to use social support networks as a way to confront the stressful situation when it comes to any kind of difficulty in treatment. This means that the person living with $\mathrm{HIV}$ often defines their family or relatives as an indispensable source of solidarity and encouragement, alleviating daily challenges and assisting in maintaining a positive outlook ${ }^{(23,25)}$.

From this perspective, a study conducted with older adults revealed that $80 \%$ of them considered their family their reason for living and the main source of strength to face a chronic disease, as it is responsible for meeting both their affective needs and the care needs; in other words, they provide love and care in facing the limitations of old age or illness, protecting older people from negative feelings and making them feel important and belonging to a group ${ }^{(11)}$.

At the same time, other studies with people living with HIV have revealed that the family is the main incentive to deal with $\mathrm{HIV}$, playing a decisive role in changing habits and routines and encouraging adherence and maintaining treatment ${ }^{(26-27)}$.

However, there are older adults who choose to keep the diagnosis confidential even from their social network. In this regard, it is believed that such an attitude is due to the fear of contempt, as social representations of HIV linked to danger and prejudice still exists in society and in the imaginations of the older adults themselves. Thus, they think that if they reveal seropositivity, their social networks are likely to suffer from the shock of diagnosis or to be afraid of becoming infected as well, expressing prejudiced attitudes and discriminatory behaviors, which may be reflected in the lack of support offered and consequently in the coping of seropositive older adults.

The fear of not being accepted in the social group or feeling abandoned and lonely are the main reasons why a person living with HIV is ashamed and decides to keep their condition confidential. Two studies of seropositive 
older adults revealed that they were sometimes reluctant to break the secrecy of their serological status, and when they revealed it was only to a single confidant, who is almost always a family member ${ }^{(26,28)}$.

In a study of older adults with HIV, the authors considered that the concern with concealing the seropositivity condition would be related to the fear of non-acceptance and a feeling of guilt, showing that such conditions may impact an increase in anxiety, depression and desire to $\mathrm{die}^{(24)}$. As a result of this fear of being marginalized, criticized and discriminated against, older adults with HIV are isolated from contact with friends, co-workers and neighbors as a way of protecting themselves ${ }^{(29-30)}$.

The social representations of HIV linked to family interaction and support are almost always focused on overcoming the diagnosis and the possibility of reorganizing life and facing HIV seropositivity.

This study was limited by the fact that data collection was performed without the interview script having undergone a pilot test for validation.

\section{CONCLUSION}

Religiosity and spirituality are sources of psychological strengthening and hope in relation to HIV. In turn, adherence to treatment, especially with regard to ART, presents itself as a concrete possibility of living, constituting something positive for the seropositive older adult.

The support coming from health professionals (institutional) and from family and friends (social network) also contributes to coping with HIV, since older adults tend to be more confident and more easily adhere to treatment by feeling respected and welcomed by these people. However, because they are aware of discriminatory and prejudiced actions by society towards an individual with HIV, seropositive older adults sometimes tend to use secrecy as another form of coping, which is reflected in their desire to be accepted and to protect themselves.

It is considered that the objective of this study was achieved, since it was possible to extract the main daily coping strategies for living with HIV from the participants' statements. The study is expected to contribute to improving the knowledge of the entire scientific community, especially health professionals who directly deal with and treat HIVpositive older people in order to promote care focused on their individual needs and encourage the development of strategies which help older adults coping with their serological condition positively.

\section{RESUMO}

Objetivo: Identificar as estratégias de enfrentamento do HIV entre idosos soropositivos. Método: Estudo exploratório-descritivo, com abordagem qualitativa, realizado com idosos soropositivos em dois Serviços de Assistência Especializada em HIV e utilizando como referencial teórico a Teoria das Representações Sociais. Utilizou-se da técnica de entrevista semiestruturada, a qual foi analisada pelo método de análise lexical por meio do software IRAMUTEQ. Resultados: Participaram do estudo 48 idosos. As estratégias de enfrentamento do HIV adotadas por idosos soropositivos são apegar-se à religiosidade e espiritualidade, aderir ao tratamento, contar com o apoio institucional dos profissionais de saúde e apoio das redes sociais, em especial família e amigos, além de optarem por manter o sigilo do diagnóstico. Conclusão: As estratégias de enfrentamento do HIV, entre outras coisas, configuram-se para os idosos soropositivos como fontes de fortalecimento, esperança, possibilidade de vida e acolhimento.

\section{DESCRITORES}

Idoso; HIV; Adaptação Psicológica; Percepção Social; Enfermagem Geriátrica.

\section{RESUMEN}

Objetivo: Identificar las estrategias de enfrentamiento del VIH entre personas mayores seropositivas. Método: Estudio exploratorio descriptivo, con abordaje cualitativo, llevado a cabo con ancianos seropositivos en dos Servicios de Asistencia Especializada en VIH, utilizándose como marco de referencia teórico la Teoría de las Representaciones Sociales. Se empleó la técnica de entrevista semiestructurada, la que fue analizada por el método de análisis lexical mediante el software IRAMUTEQ. Resultados: Participaron en el estudio 48 ancianos. Las estrategias de enfrentamiento del VIH adoptadas por las personas mayores seropositivas son: apegarse a la religiosidad y la espiritualidad, adherir al tratamiento, contar con el apoyo institucional de los profesionales sanitarios y el apoyo de las redes sociales, en especial la familia y los amigos, además de optar por mantener el sigilo del diagnóstico. Conclusión: Las estrategias de enfrentamiento del VIH, entre otras cosas, se configuran para los ancianos seropositivos como fuentes de fortalecimiento, esperanza, posibilidad de vida y acogida.

\section{DESCRIPTORES}

VIH; Anciano; Adaptación Psicológica; Apoyo Social; Enfermería Geriátrica.

\section{REFERENCES}

1. Okuno MFP, Gomes AC, Meazzini L, Scherrer Júnior G, Belasco Júnior D, Belasco AGS. Qualidade de vida de pacientes idosos vivendo com HIV/Aids. Cad Saúde Pública [Internet]. 2014 [citado 2018 maio 20];30(7):1551-9. Disponível em: http://www.scielo.br/pdf/csp/ v30n7/0102-311X-csp-30-7-1551.pdf

2. Boletim Epidemiológico Aids e DST. Brasília: Ministério da Saúde, Secretaria de Vigilância em Saúde, Departamento de Vigilância, Prevenção e Controle das Infecções Sexualmente Transmissíveis do HIV/Aids e das Hepatites Virais [Internet]. 2018 [citado 2019 jul. 12];49(53). Disponível em: http://www.aids.gov.br/pt-br/pub/2018/boletim-epidemiologico-hivaids-2018

3. Cerqueira MBR, Rodrigues RN. Factors associated with the vulnerability of older people living with HIV/AIDS in Belo Horizonte (MG), Brazil. Ciênc Saúde Coletiva [Internet]. 2016 [cited 2018 May 20];21(11):3331-8. Available from: http://www.scielo.br/pdf/csc/v21n11/ en_1413-8123-csc-21-11-3331.pdf

4. Alencar RA, Ciosak SI. Late diagnosis and vulnerabilities of the elderly living with HIV/AIDS. Rev Esc Enferm USP [Internet]. 2014 [cited 2018 May 20];49(2):227-33. Available from: http://www.scielo.br/scielo.php?script=sci_arttext\&pid=S0080-62342015000200229 
5. Araújo CLF, Aguiar PS, Santos GKA, Oliveira MGP, Câmara LS. Anti-HIV testing in gynecology services in the city of Rio de Janeiro. Esc Anna Nery [Internet]. 2014 [cited 2018 May 20];18(1):82-9. Available from: http://www.scielo.br/pdf/ean/v18n1/en_1414-8145ean-18-01-0082.pdf

6. Xu L, Lin X, Chen S, Liu Y, Liu H. Ageism, resilience, coping, family support, and quality of life among older people living with HIV/AIDS in Nanning, China. Glob Public Health. 2016;13(5):612-25. DOI: 10.1080/17441692.2016.1240822

7. Moscovici S. Representações sociais: investigações em psicologia social. 11 ${ }^{a}$ ed. Petrópolis: Vozes; 2015.

8. Minayo MCS. Pesquisa social: teoria, método e criatividade. $31^{\text {a }}$ ed. Petrópolis: Vozes; 2012.

9. Lima TCD, Gallani MCBJ, Freitas MIPD. Content validation of an instrument to characterize people over 50 years of age living with Human Immunodeficiency Virus/Acquired Immunodeficiency Syndrome. Acta Paul Enferm [Internet]. 2012 [cited 2019 July 12];25(1):410. Available from: http://www.scielo.br/pdf/ape/v25n1/en_v25n1a02.pdf

10. Oji VU, Hung LC, Abbasgholizadeh R, Hamilton FT, Essien EJ, Nwulia E. Spiritual care may impact mental health and medication adherence in HIV+ populations. HIV AIDS (Auckl) [Internet]. 2017 [cited 2018 May 21];9:101-9. Available from: https://www.ncbi.nlm. nih.gov/pmc/articles/PMC5490435/

11. Borges MS, Santos MBC, Pinheiro TG. Social representations about religion and spirituality. Rev Bras Enferm [Internet]. 2015 [cited 2018 May 21];68(4):609-16. Available from: http://www.scielo.br/pdf/reben/v68n4/0034-7167-reben-68-04-0609.pdf

12. Rocha ACAL, Ciosak SI. Chronic disease in the elderly: spirituality and coping. Rev Esc Enferm USP [Internet]. 2014 [cited 2018 May 21];48(n.spe2):87-93. Available from: http://www.scielo.br/scielo.php?script=sci_arttext\&pid=S0080-62342014000800087

13. Arrey AE, Bilsen J, Lacor P, Deschepper R. Spirituality/religiosity: a cultural and psychological resource among sub-saharan african migrant women with HIV/AIDS in Belgium. PLoS One [Internet]. 2016 [cited 2018 May 21];11(7):e0159488. Available from: https://www.ncbi. nlm.nih.gov/pmc/articles/PMC4957758/

14. Pierre S, Riviera V, Jean CP, Louis MJ, Reif LK, Severe P, et al. Live with the disease like you used to before you knew you were infected: a qualitative study among 10-year survivors living with HIV in Haiti. AIDS Patient Care STDS [Internet]. 2017 [cited 2018 May 21];31(3):14551. Available from: https://www.ncbi.nlm.nih.gov/pubmed/28282245

15. Gomes AMT, Marques SC, Apostolidis T, Nogueira VPF, Souza KPDS, França LCM. Representações sociais da espiritualidade de quem vive com aids: um estudo a partir da abordagem estrutural. Psicol Saber Soc [Internet]. 2016 [citado 2019 abr. 01];5(2):187-97. Disponível em: https://www.e-publicacoes.uerj.br/index.php/psi-sabersocial/article/view/27037/19732

16. Pecoraro A, Pacciolla A, O'Cleirigh C, Mimiaga M, Kwiatek P, Blokhina E. et al. Proactive coping and spirituality among patients who left or remained in antiretroviral treatment in St Petersburg, Russian Federation. AIDS Care. 2015;28(3):334-8. DOI: $10.1080 / 09540121.2015 .1096895$

17. Jodelet D. Representações sociais: um domínio em expansão. In: Jodelet D, organizadora. As representações sociais. Rio de Janeiro: EDUERJ; 2001.

18. Paschoal EP, Santo CCE, Gomes AMT, Santos El, Oliveira DC, Pontes APM. Adherence to antiretroviral therapy and its representations for people living with HIV/AIDS. Esc Anna Nery [Internet]. 2014 [cited 2018 May 22];18(1):32-40. Available from: http://www.scielo.br/pdf/ ean/v18n1/en_1414-8145-ean-18-01-0032.pdf

19. Rossi PS, Pereira PPG. The medicine is the least of the problems: following networks in adherence to AIDS treatment. Saúde Soc [Internet]. 2014 [cited 2018 May 22];23(2):484-95. Available from: http://www.scielo.br/pdf/sausoc/v23n2/en_0104-1290-sausoc-23-2-0484.pdf

20. Domingues JP, Oliveira DC, Marques SC. Quality of life social representations of people living with HIV/AIDS. Texto Contexto Enferm [Internet]. 2018 [cited 2019 Apr 01]; 27(2):e1460017. Available from: http://www.scielo.br/pdf/tce/v27n2/en_0104-0707-tce-2702-e1460017.pdf

21. Abara WE, Adekeye OA, Xu J, Heiman HJ, Ferrugem G. Correlates of combination antiretroviral adherence among recently diagnosed older HIV-infected adults between 50 and 64 years. AIDS Behav [Internet]. 2016 [cited 2018 May 22];20(11):2674-81. Available from: https://www.ncbi.nlm.nih.gov/pmc/articles/PMC4988927

22. Foresto JS, Melo ES, Costa CRB, Antonini M, Gir E, Reis RK. Adherence to antiretroviral therapy by people living with HIV/AIDS in a municipality of São Paulo. Rev Gaúcha Enferm [Internet]. 2017 [cited 2018 May 23];38(1):e63158. Available from: http://www.scielo.br/ pdf/rgenf/v38n1/en_0102-6933-rgenf-1983-144720170163158.pdf

23. Freitas MIF, Bonolo PF, Miranda WD, Guimarães MDC. Interactions and the antiretroviral therapy adherence among people living with HIV/AIDS. Rev Min Enferm [Internet]. 2017 [cited 2018 May 23];21:e-1001. Available from: http://www.reme.org.br/artigo/detalhes/1137

24. Caliari JS, Reinato LAF, Pio DPM, Lopes LP, Reis RK, Gir E. Quality of life of elderly people living with HIV/AIDS in outpatient follow-up. Rev Bras Enferm [Internet]. 2018 [cited 2019 Apr 02];71 Suppl 1:507-15. Available from: http://www.scielo.br/pdf/reben/v71s1/00347167-reben-71-s1-0513.pdf

25. Lee S, Yamazaki M, Harris DR, Harper GW, Ellen J. Social support and HIV-status disclosure to friends and family: implications for HIVpositive youth. J Adolesc Health [Internet]. 2015 [cited 2018 May 23];57(1):73-80. Available from: https://www.ncbi.nlm.nih.gov/pmc/ articles/PMC4478132/

26. Araldi LM, Pelzer MT, Gautério-Abreu DP, Saioron I, Santos SSC, Ilha S. Pessoas idosas com o vírus da imunodeficiência humana: infecção, diagnóstico e convivência. Rev Min Enferm [Internet]. 2016 [citado 2018 maio 23];20:e948. Disponível em: http://www.reme. org.br/artigo/detalhes/1081

27. Bonnington O, Wamoyi J, Ddaaki W, Bukenya D, Ondenge K, Skovdal M, et al. Changing forms of HIV-related stigma along the HIV care and treatment continuum in sub-Saharan Africa: a temporal analysis. Sex Transm Infect [Internet]. 2017 [cited 2018 May 23];93(n. suppl3):e052975. Available from: https://www.ncbi.nlm.nih.gov/pubmed/28736394

28. Roger KS, Mignone J, Kirkland S. Social aspects of HIV/Aids and aging: a thematic review. Can J Aging. 2013;32(3):298-306. DOI: 10.1017/ S0714980813000330 
29. Cassétte JB, Silva LC, Felício EEAA, Soares LA, Morais RA, Prado TS, et al. HIV/AIDS among the elderly: stigmas in healthcare work and training. Rev Bras Geriatr Gerontol [Internet]. 2016 [cited 2018 May 23];19(5):733-44. Available from: http://www.scielo.br/pdf/rbgg/ v19n5/1809-9823-rbgg-19-05-00733.pdf

30. Patel RC, Odoyo J, Anand K, Stanford-Moore G, Wakhungu I, Bukusi EA, et al. Facilitators and barriers of antiretroviral therapy initiation among HIV discordant couples in Kenya: qualitative insights from a pre-exposure prophylaxis implementation study. PLoS One [Internet]. 2016 [cited 2018 May 23];11(12):e0168057. Available from: https://www.ncbi.nlm.nih.gov/pmc/articles/PMC5145201/ 